\title{
Review proposes shift in US cancer funding
}

Washington. Sharp cuts in the share of research funds allocated to the intramural programme at the US National Cancer Institute (NCI) have been recommended by a panel of prominent cancer researchers. The recommendations are likely to become a blueprint for retrenchment.

The 12-member panel of university researchers has also proposed reshuffling the contents of NCI's four divisions - each of which is responsible for both intramural and extramural research on different facets of cancer biology and treatment - into two divisions, one for intramural and the other for extramural research.

Both conclusions have emerged from seven months of deliberations, and were presented last week by the panel's two chairmen, Paul Calabresi of Brown University in Providence, Rhode Island, and J. Michael Bishop of the University of California, San Francisco, to a meeting of the National Cancer Advisory Board (NCAB) on 16 May. (The full text of the panel's report will be released in mid-June.)

Other recommendations include: strengthening peer review and strategic planning of NCI's intramural research, and spinning off a significant portion of its AIDS research to sharpen the focus on cancer.

At present, NCI channels 18 per cent of its \$2-billion annual budget into its intramural programme. But, according to Bishop, that proportion increases to a massive 25 per cent when money spent on research contracts that directly support the intramural programme is included.

The latter level of support contrasts starkly with the average intramural spending of 11.3 per cent across the whole of the NIH. The panel agreed that "no single site should have such a large fraction of the federal investment in cancer research," says Bishop.

\section{work, says director}

developing safe and reliable gene therapies is the lack of suitable vectors for introducing genes into cells. "Think about how the modern day bicycle evolved from the Victorian era model," said Collins. "The basic structure was flawed - it needed a major overhaul. With gene therapy we may be arguing about the number of spokes that should be in each wheel, rather than whether we have the ideal basic design in place."

Collins said he hoped the panel "will encourage people to take chances" in working on novel vectors. Varmus, who has previously expressed concern that gene therapy may be promising more that it can deliver in the near future, told the panel that "maybe we need to let basic research percolate a bit before moving too quickly into large-scale clinical trials".

Nancy Touchette
The scrutiny comes at a difficult time in NCI's history. Harold Varmus, director of NIH, and the then NCI director Samucl Broder convened the panel late last summer in response to the call from another advisory committee for a review of the intramural programmes at each NIH institute.

Meanwhile, several senior NCI officials, including Broder (who has expressed his own unhappiness at proposals to reduce the intramural programmes), have resigned and their positions remain unfilled - although Broder's position is expected to be filled in the near future by Richard Klausner, a cell biologist at NIH.

Moreover, changes in healthcare financing are making the conduct of clinical research more difficult, as health maintenance organizations are increasingly reluctant to refer patients to the relatively more expensive hospitals where research is being carried out. And budget pressures in Congress are adding to the problem.

In this context, most researchers are likely to support the panel's conclusions, if only because they have become resigned to shrinking budgets. "If you start with the agenda that NCI must be pruned, these kinds of recommendations are appropriate," says Robert Gallo, chief of the NCI Labora-

tory of Tumor Cell Biology.

Bruce Chabner, who left his position as director of NCI's Division of Cancer Treatment in April and is now at Harvard University and Massachusetts General Hospital, says that although he does not agree with everything in the plan, "it is a reasonable attempt to reorganize the institute".

But Chabner adds that the plan's ultimate success "will depend on the people hired to execute it and the budget they are given". One concern among NCI staff is that a greater centralization of its work into two divisions could make both more vulnerable to budget cuts. Another is that any significant reduction in intramural research spending could inevitably lead to job losses among researchers at the institute.

Expressing its own form of caution, the NCAB unanimously voted to accept the panel's report "in spirit" — but reserved judgement on the details of each specific proposal. Barbara Rimer, of Duke University Medical School in Durham, North Carolina, who chairs the advisory board, said that the panel members had produced a "brilliant and comprehensive report", but that it is now up to the institute - and in particular its new director - to implement it.

Robert Taylor

\section{$\mathrm{NIH}$ backers pledge last-ditch stand}

Washington. A small but influential group of moderate Republican senators have launched a bid to save the National Institutes of Health (NIH) from proposed budget cuts which, according to NIH director Harold Varmus, could slash the success rate for grant applicants next year from 24 per cent to "between 6 and 12 per cent".

"We may fail, but at least we'll die with our boots on," said Mark Hatfield (Republican, Oregon), chair of the Senate appropriations committee, last week. Hatfield was pledging his opposition to cuts of at least 10 per cent in NIH's $\$ 11.3$ billion budget which were proposed two weeks ago by the rival Senate budget committee, chaired by Pete Domenici.

On Monday, Hatfield was trying to draft an amendment to the Senate budget resolution which would win the Senate's approval for a bid to fully restore proposed NIH cuts of $\$ 7.7$ billion over the next five years. The amendment would specify alternative targets.

Most of the 46 Democrat senators were likely to support the amendment. But Hatfield needed the support of at least 5 Republicans if the amendment was to pass. He was expected to get the support of two leading Senators who chair committees with oversight of $\mathrm{NIH}-$ Arlen
Specter (Republican, Pennsylvania) and Nancy Kassebaum (Republican, Kansas) - but other Republicans were proving difficult to recruit.

Biomedical lobbyists, aware of the possibility of defeat, have been playing down the significance of the vote, noting further opportunities to restore NIH funding cuts will arise later in the budget process.

At a hearing last week of the Labor, Health and Human Services and Education appropriations subcommittee, chaired by Specter, Varmus and his team of institute directors were asked to produce brief 'sound-bite' length assessments of the impact that such a cut would have.

In response, Varmus said the cut would cause the success rate of grant applicants to collapse. But Specter appeared impatient with the NIH team and what he interpreted as their failure to express their plight in sufficiently bald terms.

Although most members of the panel were sympathetic to $\mathrm{NIH}$, Herb Kohl (Democrat, Wisconsin) called on Varmus to "eliminate inefficiencies" at NIH. For example, Kohl wanted to know why it had 700 people working for the director's office, and why the budget of the National Library of Medicine has expanded by $\$ 35$ million.

Colin Macilwain 